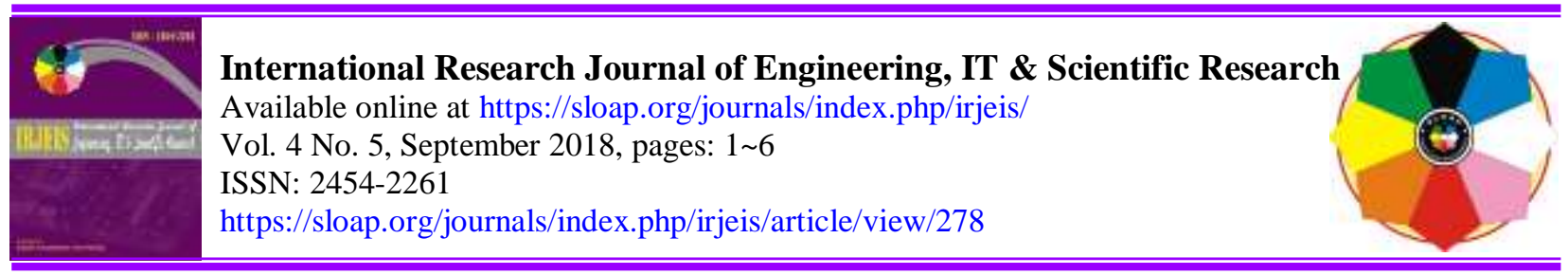

\title{
Meat Water Content Meter using Copper Electrode Sensor based on AT89S52 Microcontroller
}

\author{
I Gede Angga Rimawan a \\ I Wayan Supardi ${ }^{\text {b }}$ \\ I Putu Ari Astawa ${ }^{c}$
}

Article history:

Received: 5 May 2018

Accepted: 30 July 2018

Published: 18 August 2018

Keywords:

$A D C$;

Copper electrode;

Microcontroller;

Pork;

Water content;

\begin{abstract}
A water measuring instrument meat can be design using a copper electrode. This measuring instrument has a measuring range of $10 \%$ to $85 \%$. This series of the instrument includes copper electrode sensor, ADC0804 circuit, AT89S52 microcontroller minimum system circuit, and 2x16 character LCD circuit. The response line starts from the electrode sensor circuit of the copper converts the water content of the meat into a voltage, then the voltage is forwarded to the ADC0804 which converts the analog signal into voltage into digital data. The digital data obtained is then sent to the AT89S52 microcontroller to be processed into digital data in the form of digit display and letters on 2x16 character LCD. The display of numbers and letters on the $2 \times 16$ LCD shows the measured water content of the meat, the design tool utilizes the characteristics of a copper electrode sensor that produces a voltage change proportional to the change in the water content of the detected meat. Compatibility of design tool with the laboratory method obtained from the result of linear regression analysis of test data that is equal to $99,99 \%$.
\end{abstract}

2454-2261 ${ }^{\odot}$ Copyright 2018. The Author. This is an open-access article under the CC BY-SA license (https://creativecommons.org/licenses/by-sa/4.0/) All rights reserved.

\section{Author correspondence: \\ I Gede Angga Rimawan, \\ Faculty of Mathematics and Natural Science, Udayana University, Jimbaran, Badung, Bali-Indonesia \\ Email: anggarimawan56@gmail.com}

\section{Introduction}

With the increasing of people's need for meat consumption, irresponsible people make use of this condition by selling meat that is not suitable for consumption such as rotten meat and barking meat. Meat that is circulating on the market every day certainly has a very varied quality (Forrest, et al.; 1975). There is some benchmark for meat quality, such as elasticity level, color, smell, and water content of meat. Meat's water content indicates the weight and the quality of the meat so that consumers must be careful in choosing the meat to avoid fraudulent acts such as barking meat (Gifson, et al.; 2009).

${ }^{a}$ Faculty of Mathematics and Natural Science, Udayana University

${ }^{\mathrm{b}}$ Faculty of Mathematics and Natural Science, Udayana University

${ }^{c}$ Faculty of Biochemical Laboratory of Animal Husbandry, Udayana University 
Currently, meat weight measurement still using laboratory tests by weighing the initial weight of the meat and then roasted by using an oven binder ed-53 with a temperature of $105^{\circ} \mathrm{C}$ for 8 hours, then the meat is weighed again. The difference in initial weight and final weight is a method of determining the water content of meat. This manual method is inefficient and less effective (Lawrie, et al.; 2006).

The simplest test for more effective measurements can be done using sensors, such as copper electrode sensor. Based on the explanation above, has been designed an instrument to measuring the water content of meat by using copper electrode sensor based on the AT89S52 microcontroller (Munir, et al; 2007). This instrument is measuring the water content of meat using the meat pricking method, where the copper electrode as a resistance meter. The change in resistance is converted to voltage and processed by an analog to digital converter (ADC) and passed to the AT89S52 microcontroller. The measurement of water content will be displayed on LCD 2x16 (Saffle, et al; 1958). Within this instrument is expected to help the community in choosing meat that is suitable for consumption.

\section{Materials and Methods}

\section{Block Diagram Instruments}

The block diagram of the meat water content meter's design using copper electrode sensor based on the AT89S52 microcontroller is shown in Figure 1.

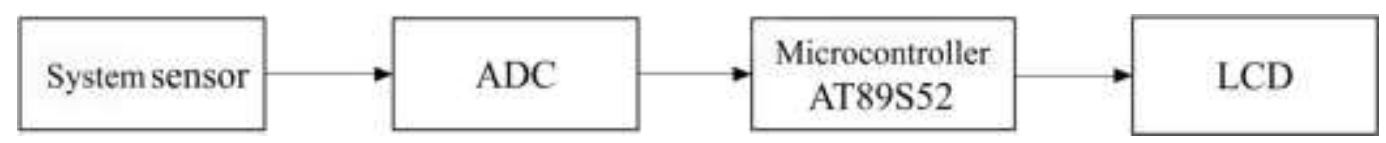

Figure 1. Block diagram of meat water content meter

The signal response flow shown in Figure 5 starts from a copper sensor that converts the input signal in the form of water content into an analog signal in the form of a voltage. Changes in the sensor output voltage can be read by the ADC to convert analog signals into digital data. The digital data that obtained from ADC then processed by AT89S52 microcontroller into digital data that forming numbers and letters on the 2x16 LCD (Simpen, et al.; 2017). The display of numbers and letters on the LCD shows measured meat water content (Simpen, et al; 2018).

\section{Results and Analysis}

\subsection{Results}

The results obtained from this study are meat water content meter by using a copper electrode sensor based on AT89S52 microcontroller (Wang, et al; 2010, Wu, et al.; 2010). This measuring instrument consists of several main components such as the copper electrode sensor, copper electrode sensor circuit, ADC0804 circuit, AT89S52 minimum system circuit, 2x16 LCD circuit, and 2x16 LCD as shown in Figure 2.

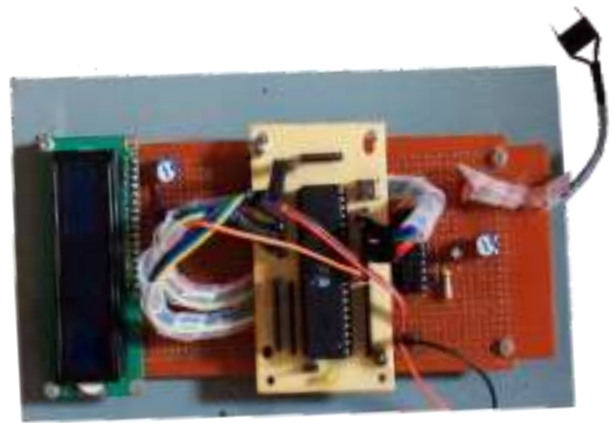

Figure 2. Measuring the water content of meat with a sensor electrode based on AT89S52 microcontroller 


\subsection{Analysis}

Testing the design of the meat water content meter by using copper electrode sensor based on AT89S52 microcontroller was done by comparing the measured measurement results with the results of measurements carried out at the Animal Husbandry and Microbiology Technology Laboratory, Faculty of Animal Husbandry, Udayana University (Wahyudin: 2007). The test was carried out by taking data on the measurement of meat water content in 5 pork samples. Five meat samples consisting of three fresh pork and two rotten pork. Data obtained from this test are shown in Table 1.

Table 1

Data on pork water content testing result

\begin{tabular}{cccc}
\hline \multirow{2}{*}{ No } & \multicolumn{2}{c}{ Meat Water Content (\%) } & \multirow{2}{*}{ Description } \\
\cline { 2 - 3 } & Comparative & Designed Instrument & Fresh \\
\hline 1 & 18,15 & 18,25 & Fresh \\
2 & 24,29 & 24,36 & Fresh \\
3 & 26,13 & 26,05 & Foul \\
4 & 63,13 & 63,03 & Foul \\
5 & 78,36 & 78,22 & \\
\hline
\end{tabular}

The linearity of measurement results between the designed instrument and the comparison was conducted using data analysis in the form of regression analysis, namely linear regression. The alignment is displayed in a gradual form as shown in Figure 3.

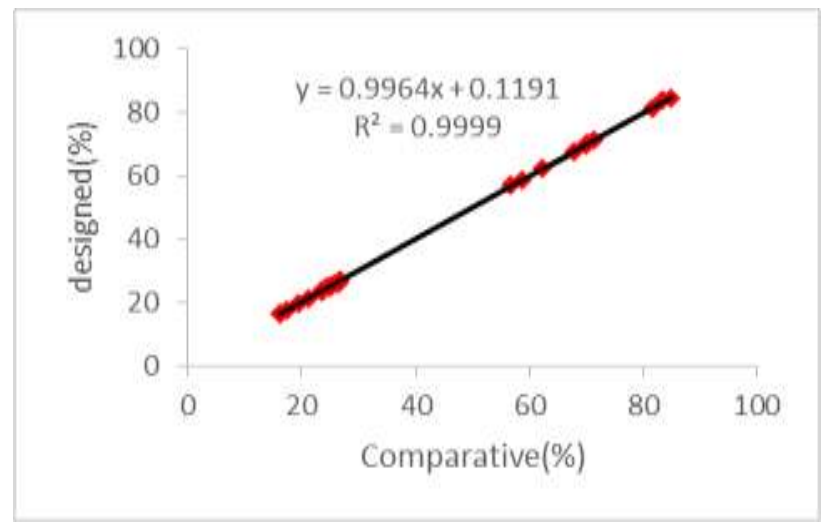

Figure 3. Linearity graphic of comparison test results and designed instrument

Figure 9 shows the graph of linearity of the results of the average measurement of pork water content by the designed instrument with the laboratory comparison method. The determinant coefficient obtained from the analysis of the designed instrument testing data is 0.9999. The coefficient states the appropriateness of the designed instrument with a comparator is $99.99 \%$ while the rest is non-conforming. The discrepancy that occurs due to the sensitivity of the sensor from the designed instrument.

\section{Conclusion}

The conclusion obtained based on this study is that it has been successfully designed a meat water content meter using a copper electrode sensor based on AT89S52 microcontroller. The alignment of testing results between designed instrument with the lab method, obtained from the results of linear regression analysis, is $99.99 \%$. These results indicate that the measurement of the meat water content meter is quite accurate.

Rimawan, I. G. A., Supardi, I. W., \& Astawa, I. P. A. (2018). Meat water content meter using copper electrode sensor based on AT89S52 microcontroller. International Research Journal of Engineering, IT \& Scientific Research, 4(5), 1-6. https://doi.org/10.21744/irjeis.v4n5.278 
Conflict of interest statement and funding sources

The author declared that they have no competing interest. The study was financed by the author.

Statement of authorship

The authors have a responsibility for the conception and design of the study. The authors have approved the final article.

\section{Acknowledgments}

This research was supported by I Wayan Supardi, S.Si., M.Si., Dr. I Putu Ari Astawa, S.Pt., MP. We thank our colleagues from Ni Made Ayu Mega Trisnayani Putri who provided insight and expertise that greatly assisted the researcher. 


\section{References}

Forrest, J. C., Aberle, E. D., Hedrick, H. B., Judge, M. D., \& Merkel, R. A. (1975). Principles of meat science. WH Freeman and Co..

Gifson, A., \& Slamet, S. (2009). Sistem Pemantau Ruang Jarak jauh dengan Sensor Passive Infrared berbasis Mikrokontroler AT89S52. TELKOMNIKA (Telecommunication Computing Electronics and Control), 7(3), 201106.

Lawrie, R. A., \& Ledward, D. A. (2006). The structure and growth of muscle: Lawrie's meat science.

Munir, M. M., Suhendi, A., Thaha, H., \& Budiman, M. (2007). An AT89S52 microcontroller-based single board computer for teaching an instrumentation system course. Computer Applications in Engineering Education, 15(2), 166-173.

Saffle, R. L. (1958). The effect of fatness on some processing and palatability characteristics of pork carcasses. Michigan State College of Agriculture and Applied Science. Department of Animal Husbandry.

Simpen, I. N., Dewi, N. P. G. B., \& Aribudiman, I. N. (2018). Relationship between resistivity and soil strength based on geoelectric data. International Journal of Life Sciences (IJLS), 2(2), 22-29.

Simpen, I. N., Redana, I. W., Pujianiki, N. N., \& Umratul, I. (2017). Aquifers Selection to Aid Geoelectrical Methods on Drilled Well Building near the Beach. International Journal of Physical Sciences and Engineering (IJPSE), 1(3), 41-50.

Wahyudin, D. (2007). Belajar Mudah Mikrokontroler AT89S52 dengan bahasa basic menggunakan Bascom8051. Yogyakarta: Andi.

Wang, J., \& Chong, J. W. (2010). Adaptive multi-level block truncation coding for frame memory reduction in LCD overdrive. IEEE Transactions on Consumer Electronics, 56(2).

Wu, H., Tang, M., \& Huang, G. (2010, May). Design of multi-functional street light control system based on AT89S52 single-chip microcomputer. In Industrial Mechatronics and Automation (ICIMA), $20102 n d$ International Conference on(Vol. 1, pp. 134-137). IEEE.

Rimawan, I. G. A., Supardi, I. W., \& Astawa, I. P. A. (2018). Meat water content meter using copper electrode sensor based on AT89S52 microcontroller. International Research Journal of Engineering, IT \& Scientific Research, 4(5), 1-6. https://doi.org/10.21744/irjeis.v4n5.278 


\section{Biography of Author}

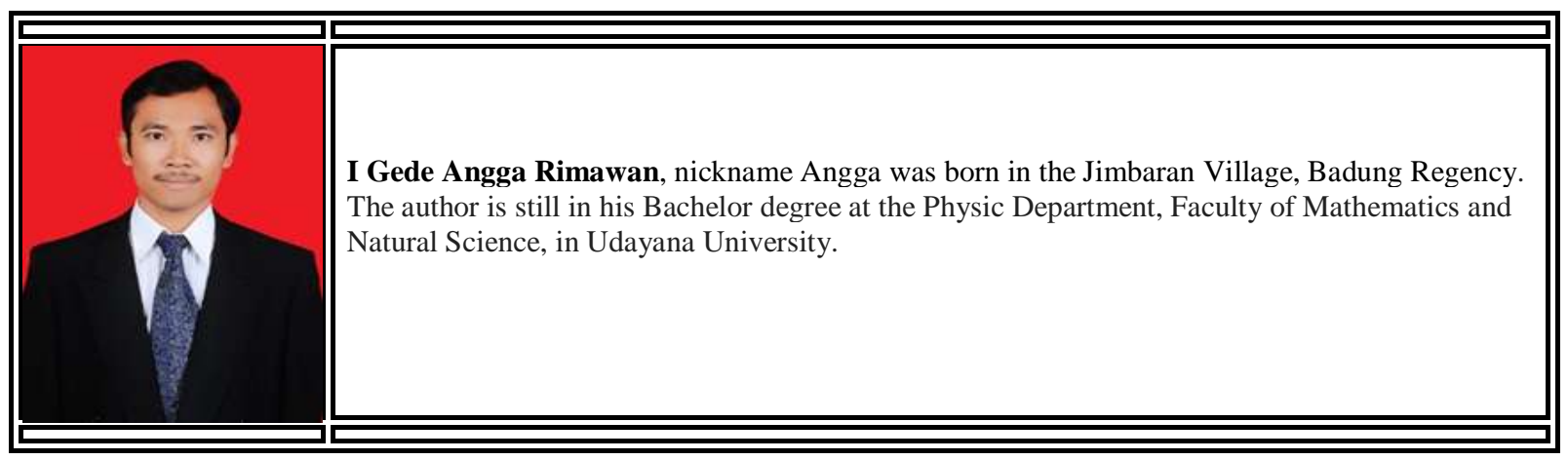

